\title{
Clinical Presentations of Monoclonal Gammopathy Cases in A Tertiary Care Referral Centre of Bangladesh
}

\author{
Monwar Tarek $^{1}$, Latifa Rahman ${ }^{2}$, Md. Manirul Islam, Nilufa Parvin ${ }^{4}$ \\ ${ }^{1}$ Classified Specialist in Pathology, Armed Forces Institute of Pathology (AFIP), Dhaka, Bangladesh; ${ }^{2}$ Associate Professor, \\ Department of Community Medicine, Armed Forces Medical College, Dhaka, Bangladesh; ${ }^{3}$ Assistant Professor, \\ Department of Haematology, Dhaka Medical College, Dhaka, Bangladesh; ${ }^{4}$ Assistant Professor, Department \\ of Obstetrics \& Gynecology, Sir Salimullah Medical College, Dhaka, Bangladesh
}

[Received: 12 November 2019; Accepted: 2 December 2019; Published: 1 January 2020]

\begin{abstract}
Background: Monoclonal gammopathy are haematologic disorder characterized by abnormal production of one or more immunoglobulin clone. Accurate detection and quantitation of monoclonal immunoglobulins is important for diagnosis and management of monoclonal gammopathies. There are very few studies related to monoclonal gammopathy in Bangladesh. This study wasaimed to observe the clinical profile and immunoglobulin pattern of monoclonal gammopathy cases in a tertiary care referral center. Objective: This study wasaimed to observe the clinical profile and immunoglobulin pattern of monoclonal gammopathy cases in a tertiary care referral center. Methodology: This cross sectional study was conducted in the Department of Haematology, Armed Forces Institute of Pathology (AFIP), Dhaka Cantonment, Dhaka. Study Period was July 2014 to Dec 2014. Patients with the age between 40 to 70 yearsof both sexes who were diagnosed as cases of monoclonal gammopathies was selected as study population. All patients were interviewed by using standard questionnaire and general medical condition of the patients was evaluated through history taking, clinical examination and laboratory investigations. Bone marrow microscopic examination, serum protein electrophoresis, immunofixationelectrophoresis (IFE), skeletal survey and relevant biochemical tests including serum creatinine, calcium, albumin and urinary BJP were performed. Protein electrophoresis of the samples was performed by automated capillary electrophoresis machine. Results: A total of 30 cases were recruited for this study. Out of 30 monoclonal gammopathy cases, majority of cases $17(56.7 \%)$ were between 60 to 70 years age group. Mean age was $57.13( \pm 9.66)$ years. Male were predominant $19(63.0 \%)$ and Male female ratio was $1.72: 1$. Among the patients, low backache and pallor was common in majority $(80 \%)$ of the cases, while fatigue and fever were present in $73.3 \%$ and $70.0 \%$ cases respectively. Among the patients, $7(23.3 \%)$ were hypertensive, $6(20.0 \%)$ were diabetic, $3(10.0 \%)$ patients were suffering from CKD with hypertension, 3(10.0\%) had bronchial asthma, 1(3.3\%) was with hypertension and Diabetes Mellitus. Depending on different laboratory findings, among all the 30 cases, $21(70 \%)$ cases were diagnosed as multiple myeloma, 5(16.6\%) cases were MGUS and 2(6.7\%) cases were Smouldering multiple myeloma and kappa light chain multiple myeloma each. Among the multiple myeloma cases, 11(36.6\%) cases had IgG Kappa monoclonal gammopathy and $6(20.0 \%)$ cases had IgG Lambda monoclonal gammopathy. Conclusion: Monoclonal gammopathy occurs predominantly in male population at around sixth decade and mostly are presented with fatigue and bone pain. Majority of the patients suffered from multiple myeloma. [Journal of National Institute of Neurosciences Bangladesh, 2020;6(1): 19-23]
\end{abstract}

Keywords: : Serum; Protein Electrophoresis; Imunofixation Electrophoresis (IFE); BenceJones protein; Multiple myeloma; M Protein

Correspondence: Lt. Col. Dr. Monwar Tarek, Classified Specialist in Pathology, Armed Forces Institute of Pathology (AFIP), Dhaka Cantonment, Dhaka, Bangladesh; Cell no.:+8801715010064; Email: tarekmonwar70@gmail.com

Conflict of interest: There is no financial conflict of interest relevant to this paper to disclose.

Funding agency: This research project was not funded by any group or any institution.

Contribution to authors: Tarek M, Rahman L have contributed from the protocol preparation, data collection up to report writing. Manuscript writing has been performed by Islam MM, Parvin N. Tarek Mhas revised the manuscript.

How to cite this article: Tarek M, Rahman L, Islam MM, Parvin N. Clinical Presentations of Monoclonal Gammopathy Cases in A Tertiary Care Referral Centre of Bangladesh. J NatlInstNeurosci Bangladesh, 2020;6(1): 19-23

Copyright: (C2020. Tarek et al. Published by Journal of National Institute of Neurosciences Bangladesh. This article is published under the Creative Commons CC BY-NC License (https://creativecommons.org/licenses/by-nc/4.0/). This license permits use, distribution and reproduction in any medium, provided the original work is properly cited, and is not used for commercial purposes. 


\section{Introduction}

The presence of abnormal monoclonal proteins, which is referred to as monoclonal gammopathy, is a frequent, characteristic feature of plasma cell dyscrasias. Monoclonal gammopathy are haematologic disorder characterized by abnormal production of one or more immunoglobulin clone. Accurate detection and quantitation of monoclonal immunoglobulins is important for diagnosis and management of monoclonal gammopathies ${ }^{1,2}$. They range from asymptomatic benign disorder such as monoclonalgammopathy of undetermined significance (MGUS) to malignant plasma cell and lymphoid disorder, including multiple myeloma and Waldenstrommacroglobulinemia ${ }^{3}$.

In particular, monoclonal immunoglobulin can be used for screening, monitoring and monitoring disease progression in MGUS. Multiple myeloma accountsfor $1 \%$ of malignant disorder, but is the most common malignant plasma cell dyscrasia and ranks second among primary haematological malignancies, with a peak incidence in the $7^{\text {th }}$ decade. The incidence of multiple myeloma(MM) is increasing rapidly in Asian countries ${ }^{4,5}$. Approximately $30.0 \%$ of monoclonal gammopathy patients (including patients with light chain myeloma, primary AL amyloidosis, non-secretory myeloma, and light chain deposition disease) produce free lightchains (FLC) as the only monoclonal component ${ }^{6}$.

The monoclonal protein is usually detected as a discrete band in the $\gamma$ or $\beta$ region in serum or urine protein electrophoresis ( $\mathrm{M}$ spike). The nature of the monoclonal protein is then characterized and confirmed by an immunofixation electrophoresis (IFE). There are very few studies related to monoclonal gammopathy in Bangladesh.Therefore, this study wasaimed to observe the clinical profile and immunoglobulin pattern of monoclonal gammopathy casesin a tertiary care referral center.

\section{Methodology}

This cross sectional study was conducted in the Department of Haematology at Armed Forces Institute of Pathology (AFIP), Dhaka Cantonment, Dhaka, Bangladesh. Study Period was July 2014 to Dec 2014. Patients aged between 40 to 70 years old with both sexes who were diagnosed as cases of monoclonal gammopathies were selected as study population. No casesofplasma cell dyscrasia with other malignancy wereincluded in the study. All patients were interviewed by using standard questionnaire which was containing socio-demographic and relevant information. General medical condition of the patients was evaluated through history taking, clinical examination and laboratory investigations. Blood sample and bone marrow aspiration were collected from the patient. Bone marrow microscopic examination, serum protein electrophoresis,immunofixationelectrophoresis (IFE), skeletal survey and relevant biochemical tests including serum creatinine, calcium, albumin and urinary Ben-Johns Protein (BJP)were performed. Protein electrophoresis of the specimens was performed by automated capillary electrophoresis machine (Capiflex-2) which was identified the various protein bands and depicted as a graph. The M band was usually found in the gamma globulin region; however, in a few cases it was identified in the beta region also. The machine identified the $\mathrm{M}$ protein both qualitatively and quantitatively.Immunofixation electrophoresis (IFE) separated the serum protein by electrophoresis followed by treatment of the protein with specific antiserum against IgG, IgA, IgM, IgD, IgE, kappa and lamda. If the $\mathrm{M}$ protein was present, a precipitated band was formed. The gel was washed with saline to extract all unprecipitated protein which was then stained followed by de-colourization and dried.

\section{Results}

A total number of 30 cases were recruited for this study. Among 30 monoclonal gammopathycases, 19 $(63.0 \%)$ were male and $11(37.0 \%)$ were female. Majority of the patients belonged to the age group of 60 to 70 years. The haemoglobin concentration was $<9$ $\mathrm{gm} / \mathrm{dl}$ in majority of the cases $(80 \%)$. It was reveled in blood film that $50 \%$ patients were suffering from anaemia of chronic disorder. In bone marrow microscopy examination, majority $(73.3 \%)$ of the patients were found suggestive of multiple myeloma. Serum protein electrophoresis test revealed that majority $(80 \%)$ of thepatientswere havingmonoclonal band ( $\mathrm{M}$ band) and 20\% hada normal findings. In IFE, $80 \%$ of the samples were positive for IgG monoclonal protein while $\operatorname{IgA}, \operatorname{IgM}$ and light chain kappa monoclonal protein were $6.7 \%$ for each group (Table $1)$.

The serum protein electrophoresis according to different immunoglobulin pattern was recorded. In IgG Kappa monoclonal gammopathy monoclonal protein ( $\mathrm{M}$ band) $93.3 \%$ cases and thenormal finding 6.7\% cases. In IgG lambda monoclonal gammopathy monoclonal protein ( $\mathrm{M}$ band) was in $66.7 \%$ cases and normal finding was in $33.3 \%$ cases. IgM Kappa monoclonal gammopathy Monoclonal protein(M band) $100.0 \%$. In IgA Kappa monoclonal gammopathy 
monoclonal protein (M band) was found in 100\% cases. In light change kappa monoclonal gammopathy normal finding was in $100.0 \%$ cases (Table 2).

Table 1: Demographic Data and Laboratory Findings of Monoclonal Gammopathy Cases $(\mathrm{n}=30)$

\begin{tabular}{|c|c|c|}
\hline Variables & Frequency & Percent \\
\hline \multicolumn{3}{|l|}{ Age Group } \\
\hline - 40 to 49 Years & 07 & 23.3 \\
\hline - 50 to 59 Years & 06 & 20.0 \\
\hline - 60 to 70 Years & 17 & 56.7 \\
\hline Mean \pm SD (Range) & \multicolumn{2}{|c|}{$57.13 \pm 9.66(40-70$ years $)$} \\
\hline \multicolumn{3}{|l|}{ Gender } \\
\hline - Male & 19 & 63.0 \\
\hline - Female & 11 & 37.0 \\
\hline \multicolumn{3}{|l|}{ Hb concentration } \\
\hline - Below 9 gm/dL & 18 & 60.0 \\
\hline $\begin{array}{l}\text { - Between } 9 \mathrm{gm} / \mathrm{dL} \text { to } \\
\text { lower normal range }\end{array}$ & 6 & 20.0 \\
\hline - Within Normal reference & 6 & 20.0 \\
\hline \multicolumn{3}{|l|}{ Peripheral Blood Film } \\
\hline - Anaemia of chronic disorder & 15 & 50.0 \\
\hline $\begin{array}{l}\text { - Microcytic hypochromic with } \\
\text { high ESR }\end{array}$ & 05 & 16.7 \\
\hline $\begin{array}{l}\text { - Neutrophil leucocytosis with } \\
\text { high ESR }\end{array}$ & 04 & 13.3 \\
\hline - None specific findings & 03 & 10.0 \\
\hline - Leuco-erythro-blastic blood picture & 03 & 10.0 \\
\hline \multicolumn{3}{|l|}{ Bone Marrow Study } \\
\hline $\begin{array}{l}\text { - Suggestive of Multiple myeloma } \\
\text { (bone marrow plasma cell >20\%) }\end{array}$ & 22 & 73.3 \\
\hline $\begin{array}{l}\text { - Plasma Cell dyscrasia } \\
\text { (bone marrow plasma cell <20\%) }\end{array}$ & 06 & 20.0 \\
\hline - Secondary Reactive Marrow & 02 & 6.7 \\
\hline \multicolumn{3}{|l|}{ Serum protein electrophoresis } \\
\hline - Monoclonal band (M band ) & 24 & 80.0 \\
\hline - Normal findings & 06 & 20.0 \\
\hline \multicolumn{3}{|l|}{ Immunofixation electrophoresis (IFE) } \\
\hline - IgG Kappa monoclonal protein & 15 & 50.0 \\
\hline - IgG Lambda monoclonal protein & 09 & 30.0 \\
\hline - IgA Kappa monoclonal protein & 02 & 06.7 \\
\hline - IgM Kappa monoclonal protein & 02 & 06.7 \\
\hline - Light change kappa monoclonal prot & ein 02 & 06.7 \\
\hline
\end{tabular}

Clinical characteristics of monoclonal gammapathy patients were summarized. Among all patients,low backache and pallor were common in majority $(80.0 \%)$ cases while fatigue and fever werepresent in $73.3 \%$ cases and $70.0 \%$ cases respectively.Among all patients, $7(23.3 \%)$ cases were hypertensive, $6(20.0 \%)$ cases were diabetic, $3(10.0 \%)$ cases were suffering from chronic kidney disease (CKD) with hypertension, $3(10.0 \%)$ cases had bronchial asthma,1(3.3\%) case was withhypertension and Diabetes Mellitus in each (Table 3).

Table 3:Clinical characteristics and Co-morbidities Associated with Monoclonal Gammapathy Patients $(\mathrm{n}=30)$

\begin{tabular}{lcc}
\hline Variables & Frequency & Percent \\
\hline Clinical features & 24 & 80.0 \\
Pallor & 15 & 50.0 \\
Spine tenderness & 12 & 30.0 \\
Odema & 22 & 73.3 \\
Fatigue & 24 & 80.0 \\
Bone pain & 18 & 60.0 \\
Weight loss & 21 & 70.0 \\
Fever & 14 & 46.6 \\
Constipation & 10 & 33,3 \\
Cough & & \\
Co-morbidities associated with & \\
monoclonal gammapathy & & 23.3 \\
HTN & 07 & 20.0 \\
DM & 06 & 10.0 \\
CKD with HTN & 03 & 10.0 \\
Bronchial asthma & 03 & 03.3 \\
HTN with DM & 01 & 33.3 \\
Co-morbidity absent & 10 & \\
\hline HTN=Hypertension; CKD=Chronic Kidney Disease; & \\
DM=Diabetes mellitus & & \\
& &
\end{tabular}

In IgG Kappa monoclonal gammopathy patients, renal insufficiency was present in $33.3 \%$ cases, hypercalcaemiain $40 \%$ cases, urinary BJP was detected in $26.7 \%$ cases (Table-4). In IgG lambda monoclonal gammopathy, renal insufficiency was present in $77.7 \%$ cases, hypercalcaemia in $44.4 \%$ cases and urinaryBJPwas present in $44.4 \%$ cases.

Table 2: Monoclonal component absent in serum protein electrophoresis but present in serum immunofixastion electrophoresis $(n=30)$

\begin{tabular}{|c|c|c|c|c|c|}
\hline \multirow{2}{*}{$\begin{array}{l}\text { Serum protein } \\
\text { electrophoresis }\end{array}$} & \multicolumn{5}{|c|}{ Serum immunoglobulin pattern } \\
\hline & $\begin{array}{l}\text { IgG Kappa } \\
\text { monoclonal } \\
\text { gammopathy } \\
(\mathrm{n}=15)\end{array}$ & $\begin{array}{l}\text { IgG Lambda } \\
\text { monoclonal } \\
\text { gammopathy } \\
(\mathrm{n}=9)\end{array}$ & $\begin{array}{l}\text { IgM Kappa } \\
\text { monoclonal } \\
\text { gammopathy } \\
(n=2)\end{array}$ & $\begin{array}{c}\text { IgA Kappa } \\
\text { monoclonal } \\
\text { gammopathy } \\
(\mathrm{n}=2)\end{array}$ & $\begin{array}{l}\text { Light chain kappa } \\
\text { monoclonal } \\
\text { gammopathy } \\
(\mathrm{n}=2)\end{array}$ \\
\hline Normal finding & $\begin{array}{c}14(93.3) \\
01(6.7)\end{array}$ & $\begin{array}{c}6(66.7) \\
03(33.3)\end{array}$ & $\begin{array}{c}02(100) \\
0\end{array}$ & $\begin{array}{c}02(100) \\
0\end{array}$ & $\begin{array}{c}0(0) \\
2(100)\end{array}$ \\
\hline
\end{tabular}


Table 4: Distribution of Biochemical Change in Different Immunoglobulin Pattern (monoclonal gammopathy)

\begin{tabular}{|c|c|c|c|c|c|}
\hline \multirow{2}{*}{$\begin{array}{l}\text { Biochemical } \\
\text { Change }\end{array}$} & \multicolumn{5}{|c|}{ Serum immunoglobulin pattern } \\
\hline & $\begin{array}{l}\text { IgG Kappa } \\
\text { monoclonal } \\
\text { gammopathy } \\
(\mathrm{n}=15)\end{array}$ & $\begin{array}{c}\text { IgG Lambda } \\
\text { monoclonal } \\
\text { gammopathy } \\
(\mathrm{n}=9)\end{array}$ & $\begin{array}{c}\text { IgM Kappa } \\
\text { monoclonalgam } \\
\text { mopathy } \\
(\mathrm{n}=2)\end{array}$ & $\begin{array}{c}\text { IgA Kappa } \\
\text { monoclonal } \\
\text { gammopathy } \\
(\mathrm{n}=2)\end{array}$ & $\begin{array}{l}\text { Light chain kappa } \\
\text { monoclonal } \\
\text { gammopathy } \\
(\mathrm{n}=2)\end{array}$ \\
\hline $\begin{array}{l}\text { Renal insufficiency } \\
(\mathrm{S} . \text { creatinine }>2.0 \mathrm{mg} / \mathrm{dL})\end{array}$ & $5(33.3 \%)$ & $7(77.7 \%)$ & $0(0.0 \%)$ & $2(100.0 \%)$ & $2(100.0 \%)$ \\
\hline Hypercalcaemia( $11.0 \mathrm{mg} / \mathrm{dL})$ & $6(40.0 \%)$ & $4(44.4 \%)$ & $1(50.0 \%)$ & $1(50.0 \%)$ & $2(100.0 \%)$ \\
\hline $\begin{array}{l}\text { Bence-Jones protein } \\
\text { (BJP)present }\end{array}$ & $8(53.3 \%)$ & $4(44.4 \%)$ & $0(0.0 \%)$ & $2(100.0 \%)$ & $2(100.0 \%)$ \\
\hline
\end{tabular}

Table 5: Immunoglobulinpattern in different monoclonal gammopathies.

\begin{tabular}{lcccc}
\hline Pattern of monoclonal & \multicolumn{3}{c}{ Diagnosis } \\
\cline { 2 - 5 } immunoglobulin & $\begin{array}{c}\text { Multiple } \\
\text { myeloma }\end{array}$ & $\begin{array}{c}\text { Smouldering } \\
\text { multiple myeloma }\end{array}$ & MGUS & $\begin{array}{l}\text { Kappa light chain } \\
\text { multiple myeloma }\end{array}$ \\
\hline IgG Kappa & $11(36.6 \%)$ & $2(6.7 \%)$ & $2(6.7 \%)$ & $0(0.0 \%)$ \\
IgG Lambda & $6(20.0 \%)$ & $0(0.0 \%)$ & $3(10.0 \%)$ & $0(0.0 \%)$ \\
IgM Kappa & $2(6.7 \%)$ & $0(0.0 \%)$ & $0(0.0 \%)$ & $0(0.0 \%)$ \\
IgA Kappa & $2(6.7 \%)$ & $0(0.0 \%)$ & $0(0.0 \%)$ & $0(0.0 \%)$ \\
Light chain kappa & $0(0.0 \%)$ & $0(0.0 \%)$ & $0(0.0 \%)$ & $2(6.7 \%)$ \\
Total (n=30) & $\mathbf{2 1 ( 7 0 \% )}$ & $\mathbf{2 ( 6 . 7 \% )}$ & $\mathbf{5 ( 1 6 . 6 )}$ & $\mathbf{2 ( 6 . 7 \% )}$ \\
\hline
\end{tabular}

\section{Discussion}

In this study was taken to study the clinical profile of monoclonal gammopathy casesand theirimmunoglobulinpattern intertiarycarereferral centre. It was observed that monoclonal gamapathies predominantly occur in old age (mean age $57.13 \pm 9.66$ years) and a male dominant disease (Male: Female 1.72:1). Shaheen et $\mathrm{al}^{7}$ study also reported that, mean age of occurrenceof monoclonal gammapathies is 58 years with a range of 23 to 86 years and male female ratio was $1.35: 1$. In addition, other studies from Asian countries also supports our findings ${ }^{8,9}$. Anaemia observed among the monoclonal gamopathy patients in present study was also reported before by Talerman et $\mathrm{al}^{10}$ study,where they observed $74 \%$ of cases were having anaemia while Shaheen et $\mathrm{al}^{7}$ found heamoglobin below normalin $90 \%$ cases. The reason for anaemia can be either as a result of renal impairment or can be due to bone marrow failure because of marrow infiltration by myeloma cells. In present study, monoclonal M-band was present in $80 \%$ cases while Yasseen et $\mathrm{al}^{11}$ found M-bandin $93.75 \%$ cases.

Though in a previous study ${ }^{12} 56 \%$ common clinical presentation was bone related, we observed most common symptoms in our study were bone pain in $80.0 \%$ cases supported by similar study report by Kyle et $\mathrm{al}^{13}$. In present study, fatigue was found in $73.3 \%$ cases, which was similar to study performed by Shaheenet $\mathrm{al}^{7}$. In present study, pallor was present in 80 $\%$ cases though $56 \%$ and $65 \%$ was detect in other studies $^{7,10}$. Pallor indicateanaemia. In present study, the percentage of pallor $(80 \%)$ was similar to the percentage of patients who were found to have hemoglobin level less than normal reference indicating anaemia. Hypertension and Diabetes mellitus was around $20 \%$ of co-morbidities associated with monoclonal gammapathy observed in current study which similar to the study performed by Fousadet $\mathrm{al}^{14}$. In the present study, out of 30 monoclonal gammopathy cases, $\mathrm{M}$ band identifiedin $80 \%$ cases by conventional serum protein electrophoresis whereas by the IFE method found the presence of M band in 100\% cases. Tate et al ${ }^{15}$ also observed $\mathrm{M}$ band in $74.3 \%$ $87.0 \%$ cases by serum protein electrophoresis, however through IFE the detection increased to $97.4 \%$. This occurs due to sensitivity and specificity of the IFE method $^{16}$. It is known that majority of those missed M-proteins are in MGUS group which fall in the low risk of progression to Multiple myeloma. The presence of specific Immunoglobulin in M Band categories by immunofixation method. Majority (50\%) of the cases under this study were IgG Kappa and 30\% were IgG Lambda monoclonal protein, comprising total $80 \%$ of 
the cases. Predominance of IgGmonoclonal gammopathies such as $71.47 \%, 51.40 \%$ and $57 \%$ of the total cases was observed in different studies $^{17,18,19}$ followed by IgAmonoclonal gammopathies.

Several biochemical tests were performed in current study to see the level of serum creatinine, albumin and calcium and urinary Bence Jones protein. In 53.3\% cases of monoclonal gammopathies, serum creatinine was detected $>2 \mathrm{mg} / \mathrm{dl}$ indicating renal insufficiency which support the previous study findings ${ }^{9,13}$. Lee et $\mathrm{al}^{20}$ detected lambda chain myeloma as the highest risk $(100.0 \%)$ of developing renal insufficiency. In present study though the sample size was too small, we also detected $100.0 \%$ renal insufficiency in the same group. This study shows urine for Bence Jones protein was present more than fifty percent of study population which was similar to study performed by Youinouet $\mathrm{al}^{18}$. Hypoalbuminaemia $(<3.5 \mathrm{mg} / \mathrm{dl})$ found in $70 \%$ of the monoclonal gammopathies patientsobserved in present studyshows similarity of study done by Shaheenet $\mathrm{al}^{7}$.

\section{Conclusion}

This study showsmonoclonal gammopathy occurs predominantly in male population at around sixth decade of life where fatigue and bone pain were most common symptoms and majority had spine tenderness on examination. Laboratory findings indicates that a large number of patients have been suffering from multiple myeloma.

\section{References}

1. Durie BG, Kyle RA, Belch A, et al. Myeloma management guidelines: a consensus report from the Scientific Advisors of the International Myeloma Foundation. Hematol J 2003;4:379-98

2. Guidelines Working Group of UK Myeloma Forum; British Commitee for Standards in Haematology, British Society for Haematology. Guidelines on the diagnosis and management of AL amyloidosis. Br J Haematol2004 ;125:681-00

3. Swerdlow SH, Campo E,Harris NL, et al. WHO Classification of tumours of Haematopoietic and lymphoid tissues. 4th ed. Lyon, France: International Agency for research on Cancer , 2008

4. Lee JH, Lee DS, Lee JJ, Chang YH, Jin JY, JoDY, et al. Multiple myeloma in Korea: Past, present, and futureperspectives. Experience of the Korean Multiple Myeloma Working Party. IntJHematol2010;92:52 7.
5. Huang SY, Yao M, Tang JL, Lee WC, Tsay W, Cheng AL, et al. Epidemiology of multiple myeloma in Taiwan:Increasing incidence for the past 25 years and higher prevalence of extramedullarymyeloma in patients younger than 55 years. Cancer 2007;110:896 905

6. Bradwell AR, Mead GP, Carr-Smith HD. Serum Free Light Chain Analysis, 215 (The Binding Site, Ltd., Birmingham, UK, 2005)

7. Shaheen H, Ghanghroo I, Malik I. Clinicopathological features and management of Pakistani patients with multiple myeloma.J Pak Med Assoc. 1999;49(10):233-37

8. Kim K, Lee JH, Kim JS, Min CK, Yoon SS, Shimizu K, et al. Clinical profiles of multiple myeloma in Asia - An Asian Myeloma Network study. Am J Hematol2014;89:751 6

9. Kaur P, Shah BS, Baja P. Multiple myeloma: A clinical and pathological profile. Gulf J Oncology 2014;1:14 -20

10. Talerman A. Clinico-Pathological study of multiple Myeloma in Jamaica, Pathology Department, University of the West Indies, Kingston, Jamaica, 1969;22(1):285-93

11. YasseenKM, Kh.Elmeshhedany A, Al.Obidi DS. Skeletal Manifestations and Role of Dexa Study in 32 Patients with Multiple Myeloma,The Iraqi Postgraduate Medical Journal, 2007;6(4):307-13

12. Sridhar S, Dutta TK, Basu D. Clinical profile of multiple myeloma and effect of thalidomide based treatment on its outcome. J Indian Med Assoc 2011;109:880 2, 8878

13. Kyle RA, Gertz MA, Witzig TE, Lust JA, Lacy MQ, Dispenzieri A, et al. Review of 1027 patients with newly diagnosed multiple myeloma. Mayo ClinProc 2003;78:21 33

14. Fousad C, Gangadharan KV, Abdullah C, Narayan R et al. Clinical profile of multiple myeloma in south India. Indian Journal of Medical and Paediatric Oncology, 2018; 39 62-66

15. Tate J, Mollee P, Johnson R. Monoclonal GammopathiesClinical and Laboratory Issues. ClinBiochem Rev 2009;30(8):89-91

16. Katzmann JA, Stankowski-Drengler TJ, Kyle RA, Lockington KS, Snyder MR, Lust JA, et al. Specificity of Serum and Urine Protein Electrophoresis for the Diagnosis of Monoclonal Gammopathies, Clinical Chemistry 2010;56:12:1899-00

17. Riccaracdi A, Ucci U, Luoni R, Castello A, Coci A, Magrini U, et al. Bone marrow biopsy in monoclonal gammopathies: correlations between pathological findings and clinical data. J clinPathol1990;43:469-75

18. Youinou P, Le Goff P, Saleun JP, Jouquan J, Tymen G, Le Menn G. Monoclonal gammapathies. Critical review of 219 cases collected over 3 years. PatholBiol(Paris).1977;25(8):517-21

19. Steingrimsdottir H, Haraldsdottir V, Olafsson I, Gudnason V, Ogmundsdottir HM. Monoclonal gammopathy: natural history studied with a retrospective approach. Haematologica 2007;92:1131-34

20. Lee LN, Jan IS, Tien HF, Lin JS, Lo SC, Cheng WC. Laboratory and clinical characterization of monoclonalgammopathy in Taiwanese.JFormos Med Assoc. 2002;101(2):91-07 